\title{
Twistin' the night away: gallbladder torsion accompanying large bowel malignancy
}

\author{
Sumer Shikhare, F.R.C.R., ${ }^{1}$ Michael Clarke, F.RANZCR., ${ }^{1}$ Trishna Shimpi, F.R.C.R. \\ Cheah Yee Lee, ABSC (US) ${ }^{2}$
}

${ }^{1}$ Department of Diagnostic Radiology, Khoo Teck Puat Hospital, Alexandra Health, Singapore

${ }^{2}$ Department of Surgery, Hepatobiliary and Pancreatic Surgery, Khoo Teck Puat Hospital, Alexandra Health, Singapore

\begin{abstract}
Gallbladder (GB) torsion is a rare surgical emergency seen in the elderly. It occurs due to the rotation of the gallbladder along the axis of the cystic artery and cystic duct. This study aimed to report a case of an acute GB torsion in an elderly female patient diagnosed by multi-detector computed tomography (MDCT). The clinical and imaging features of GB torsion, which can be used to assist in the preoperative diagnosis, were also discussed with emphasis on CT criteria.
\end{abstract}

Key words: Computed tomography; gallbladder torsion; large bowel malignancy; preoperative diagnosis.

\section{INTRODUCTION}

Gallbladder (GB) torsion is an extremely rare condition seen in the elderly population. ${ }^{[I]} A$ patient with GB torsion requires prompt surgical intervention due to the potential risk of necrosis and perforation. However, pre-operative diagnosis of GB torsion is nearly impossible owing to the vague clinical presentation. With advancement in imaging modalities, pre-operative radiological diagnosis of GB torsion has now become possible. In this study, it was aimed to report one such case where an elderly female patient presented with non-specific abdominal pain and was found to have GB torsion and transverse colon malignancy on contrast enhanced MDCT scan.

\section{CASE REPORT}

An 86-year-old woman came to the emergency department of our hospital with complaints of generalized colicky abdominal pain and vomiting. The patient had no significant past surgi-

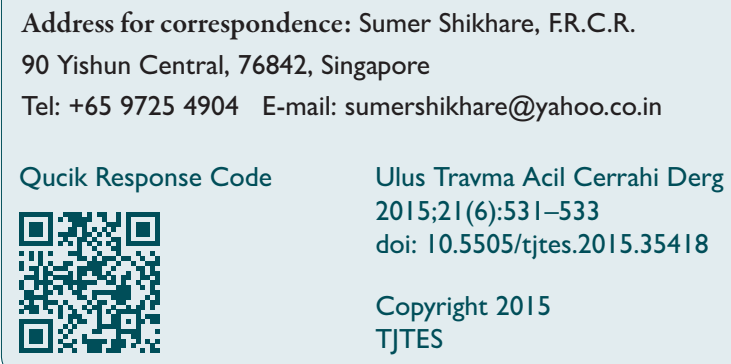

cal history. Her vital signs were normal. Physical examination demonstrated tenderness and guarding in the right iliac fossae region with negative Murphy's and Rovsing's sign. Laboratory investigations showed hemoglobin of $11.6 \mathrm{~g} / \mathrm{dL}$ ( I I.5 to 15.0), a leukocyte count of $16.66 \times 10 \% / \mathrm{L}$ (4.00 to II.00) and C-reactive protein of $30.9 \mathrm{mg} / \mathrm{L}$ ( $\mathrm{I}$ to 5 ). Liver function tests and bilirubin were normal. A contrast enhanced MDCT scan of her abdomen showed transverse colon mass causing bowel obstruction (Fig. I). It also demonstrated a markedly distended gallbladder with pericholecystic fluid. No gallstones were present. Furthermore, the MDCT images clearly revealed twisted cystic duct and gallbladder mesentery giving "whirl sign", in addition to well enhancing cystic duct (Figs. 2a, b). These findings favored the diagnosis of gallbladder torsion. The patient underwent emergency laparotomy and was found to have torsed and gangrenous gallbladder (Fig. 2c). The gallbladder was untwisted and dissected from the liver bed using a Bovie diathermy. Transverse colon segmental resection was also performed with colostomy. Pathological examination revealed extensive transmural necrosis of gallbladder wall, consistent with infarction. There was no evidence of malignancy. Specimen of the transverse colon revealed moderately-differentiated adenocarcinoma. The patient recovered without any surgical complications and was discharged about two weeks after surgery. Follow-up MDCT study after three months revealed multiple hepatic metastases secondary to colonic malignancy (Fig. 3).

\section{DISCUSSION}

GB torsion was first described by Wendel in 1898 , and it is a 


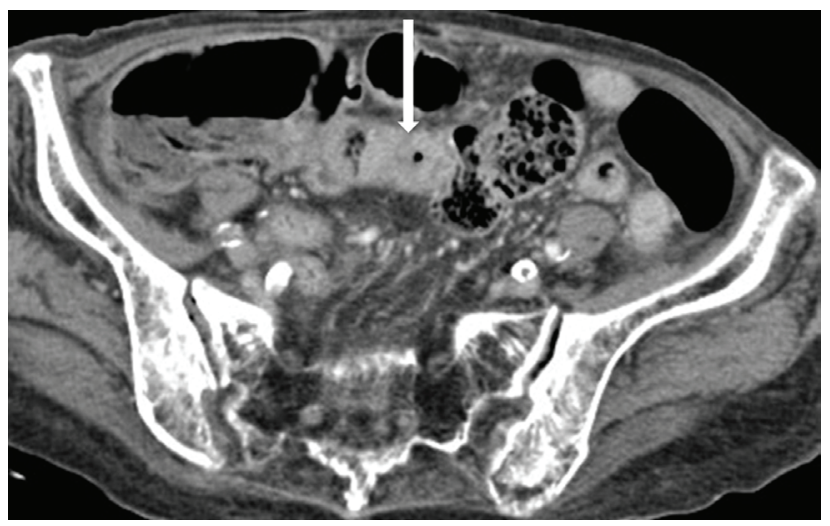

Figure 1. A contrast enhanced MDCT scan of the abdomen demonstrates obstructing transverse colon mass.

rare condition, being reported in only I of 365,520 hospital admissions. ${ }^{[2]}$ The incidence of GB torsion increases with age and is more common in elderly women, with a male to female ratio of $1: 3 .{ }^{[1,3]} \mathrm{GB}$ torsion occurs when it rotates along the long axis of the cystic artery and cystic duct. Predisposing factors for this rotation are either short/absent mesentery or long mesentery resulting in a free floating gallbladder. Other

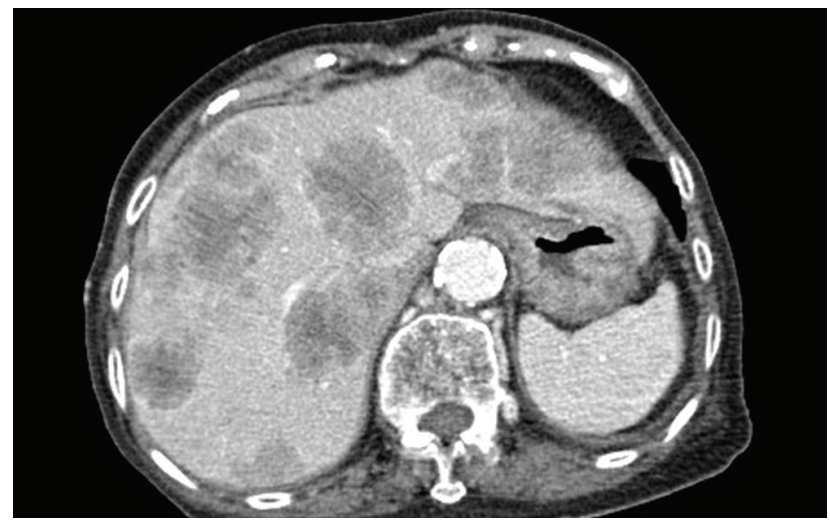

Figure 3. Three months follow up contrast enhanced MDCT scan of the abdomen demonstrates multiple hepatic metastases.

recognized factors are loss of tissue elasticity and weakening of abdominal ligaments. Factors which accelerate torsion include increased or violent peristalsis of the bowel loops on right side of the abdomen, adhesions, kypho-scoliosis, and cystic artery calcification. ${ }^{[2,4]}$ Strikingly in our case, the patient was an elderly with violent peristalsis due to obstructive transverse colon mass.


Figure 2. (a) Sagittal reformatted and axial contrast enhanced MDCT scan of upper abdomen demonstrates twisted cystic duct and gallbladder mesentery giving a "whirl sign" (arrow). Additionally it also reveals an enhancing cystic duct (curved arrow); (b) Diagrammatic representation of mechanism of gallbladder torsion. (c) Intra-operative photograph of gallbladder torsion shows point of torsion (arrow) and ' $\mathrm{x}$ ' marking body of gallbladder. 
GB torsion is categorized into two types based on the degree of rotation: (i) incomplete ( $<180$ degrees) and (ii) complete (>180 degrees). The incomplete variety presents with intermittent symptoms of biliary colic, while the complete torsion causes vascular strangulation leading to gangrenous cholecystitis. ${ }^{[1,4]}$

Patients with GB torsion commonly present with non-specific signs and symptoms, such as acute onset abdominal pain with or without vomiting. ${ }^{[4]}$ Clinical presentation mimics other intra-abdominal conditions like acute cholecystitis or acute appendicitis. Physical examination in some cases may reveal a tender mobile mass compatible with a freely mobile gallbladder. $^{[4]}$ Our patient presented with features of bowel obstruction and abdominal pain. Liver function tests are usually normal. Onset of gangrenous cholecystitis is generally marked by the increase in C-reactive protein and white blood cells count, as seen in our case. ${ }^{[4]}$ Imaging investigations play an important role and can give a definitive diagnosis of GB torsion pre-operatively. ${ }^{[4]}$ On ultrasound and MDCT images, the gallbladder is usually located inferior to its normal anatomical position, is grossly distended and has diffusely thickened and edematous wall with associated pericholecystic free fluid. ${ }^{[4]}$ These findings are non-specific and non-conclusive and can be seen in other conditions like acute cholecystitis. Kitagawa $\mathrm{H}$ et al. have postulated three criteria to help diagnose GB torsion on MDCT imaging: (i) horizontal position of the gallbladder along its long axis, (ii) fluid in between the liver bed and gallbladder, and (iii) well-enhanced cystic duct on the right side of the gallbladder. ${ }^{[3,4]} \mathrm{A}$ rare, but more specific finding on MDCT, which strongly supports the diagnosis of torsion, is "whirl sign", as seen in our case. The whirl sign has been described by Tajima $Y$ et al. and represents twisted pedicle of the cystic duct and mesentery. ${ }^{[5]}$ Magnetic resonance imaging allows easy detection of the hemorrhagic infarct and necrosis within the gallbladder wall, seen as high signal intensity on $\mathrm{TI}$ - weighted images. ${ }^{[4]}$ If undiagnosed, the commonest complication is perforation, as torsion causes impaired venous drainage consequently causing gallbladder ischemia and necrosis. Hence, it is imperative to diagnose this entity at an early stage followed by prompt surgical intervention which may help reduce the mortality to less than $5 \%{ }^{\left[{ }^{4]}\right.}$ The diagnosis of GB torsion requires emergency cholecystectomy. ${ }^{[4]}$

In conclusion, if there is strong clinical suspicion and MDCT reveals features of acalculus cholecystitis, "whirl sign" and an abnormal horizontal location of the gallbladder, definitive diagnosis of GB torsion can be made, and hence, avoid surgical delay.

Conflict of interest: None declared.

\section{REFERENCES}

1. Caliskan K, Parlakgumus A, Koc Z, Nursal TZ. Acute torsion of the gallbladder: a case report. Cases J 2009;2:6641. CrossRef

2. Boonstra EA, van Etten B, Prins TR, Sieders E, van Leeuwen BL. Torsion of the gallbladder. J Gastrointest Surg 2012;16:882-4. CrossRef

3. Kitagawa H, Nakada K, Enami T, Yamaguchi T, Kawaguchi F, Nakada $\mathrm{M}$, et al. Two cases of torsion of the gallbladder diagnosed preoperatively. J Pediatr Surg 1997;32:1567-9. CrossRef

4. Janakan G, Ayantunde AA, Hoque H. Acute gallbladder torsion: an unexpected intraoperative finding. World J Emerg Surg 2008;3:9. CrossRef

5. Tajima Y, Tsuneoka N, Kuroki T, Kanematsu T. Clinical images. Gallbladder torsion showing a "whirl sign" on a multidetector computed tomography scan. Am J Surg 2009;197:9-10. CrossRef

\section{OLGU SUNUMU - ÖZET}

\section{Geceyi zehir etmek, kalın bağırsak malinitesinin eşlik ettiği safra kesesi torsiyonu}

\section{Dr. Sumer Shikhare, ${ }^{1}$ Dr. Michael Clarke, ${ }^{1}$ Dr. Trishna Shimpi, ${ }^{1}$ Dr. Cheah Yee Lee ${ }^{2}$}

${ }^{1}$ Alexandra Sağlık, Khoo Teck Puat Hastanesi, Tanısal Radyoloji Bölümü, Singapur

${ }^{2}$ Alexandra Sağlık, Khoo Teck Puat Hastanesi, Cerrahi Kliniği, Hepato-Pankreato-Bilier Cerrahi Bölümü, Singapur

Safra kesesi (SK) torsiyonu yaşlılarda seyrek görülen acil bir durumdur. Safra kesesinin kist arter ve kanalı ekseni çevresinde dönmesi nedeniyle oluşur. Bu çalışma yaşlı bir kadın hastada multidedektörlü bilgisayarlı tomografi (BT) ile tanı konmuş bir akut SK torsiyonu olgusunu raporlamayı amaçlamışıı. Safra kesesi torsiyonunun ameliyat öncesi tanısına yardımcı olmak için kullanılabilen klinik ve görüntüleme özellikleri BT kriterleri vurgulanarak tartışıımıştır.

Anahtar sözcükler: Ameliyat öncesi tanı; bilgisayarlı tomografi; kalın bağırsak malinitesi; safra kesesi torsiyonu.

Ulus Travma Acil Cerrahi Derg 2015;2I (6):53I-533 doi: 10.5505/tjtes.2015.354I8 